\title{
SHORT COMMUNICATION \\ Induction of Phenotypically Determined Resistance of Neisseria gonorrhoeae to Human Serum by Factors in Human Serum
}

\author{
By P. M. V. MARTIN, $\dagger$ P. V. PATEL, N. J. PARSONS AND \\ H. SMITH* \\ Department of Microbiology, University of Birmingham, PO Box 363, \\ Birmingham B15 2TT, U.K.
}

(Received 6 March 1981; revised 11 June 1981)

\begin{abstract}
Of 47 human sera tested, 13 converted serum-sensitive gonococci [strain BS4 (agar)] to serum resistance in vitro in $3 \mathrm{~h}$ at $37^{\circ} \mathrm{C}$, as had previously been demonstrated for most samples of guinea pig serum. The resistance-inducing activity of human serum was lower than that of guinea pig serum but, like the latter, did not operate at $8{ }^{\circ} \mathrm{C}$, was greater at $\mathrm{pH} 6.6$ than at pH 7.1, was increased by freezing and thawing, and depended on high and low molecular weight serum fractions; the latter fraction had a molecular weight between 1000 and 5000 , and was acid- and heat-labile.
\end{abstract}

\section{INTRODUCTION}

Neisseria gonorrhoeae isolated from disseminated infections and from human urethral pus are resistant to killing by normal human serum (Schoolnik et al., 1976; Ward et al., 1970). This resistance may be important not only in the pathogenesis of disseminated gonorrhoea (Brooks et al., 1978) but also in the acute disease, as serum factors will escape on to mucous surfaces during inflammation and tissue damage. Serum resistance of gonococci grown in vivo was also seen in organisms obtained from infected plastic chambers implanted subcutaneously in guinea pigs (Penn et al., 1976). The serum resistance was of two types. Gonococci from disseminated gonorrhoea and some of the strains from urethral exudates and guinea pig chambers exhibited a resistance which was retained on subculture in vitro (Schoolnik et al., 1976; Ward et al., 1970; Penn et al., 1977). The second type of resistance, in which we are interested, was lost on subculture in vitro and was shown by most of the strains from urethral exudates (Ward et al., 1970) and guinea pig chambers (Penn et al., 1977).

Using the guinea pig system as a model, it was shown that the changes from resistance (in vivo) to sensitivity (in vitro) and vice versa were phenotypic (Rittenberg et al., 1977). In later studies, susceptible organisms were rendered resistant in vitro by short-term growth at $37^{\circ} \mathrm{C}$ in fluid from the subcutaneous chambers, or in heat-inactivated guinea pig serum. A mixture of serum diffusate of the latter (mol. wt $<12000$ ) and a chemically defined medium containing 0.1\% (w/v) bovine serum albumin (Rittenberg et al., 1977; Goldner et al., 1979; Veale et al., 1981) also induced resistance. The diffusible serum factor had a molecular weight of between 1000 and 5000 (Veale et al., 1980) and was acid- and heat-labile.

This paper describes the investigation of human sera for the presence of resistance-inducing factors akin to those in guinea pig serum. McCutchan et al. (1976) described serum resistance

† Permanent address: Unité d'Ecologie bacterienne, Institut Pasteur, Rue du Docteur Roux, Paris, France. 
acquired by selecting gonococci that survived incubation for $1 \mathrm{~h}$ in fresh human serum in vitro. This resistance disappeared after two overnight subcultures on agar, but it differed from the phenotypically acquired resistance of gonococci derived from the guinea pig system, which appeared to be more complete and was lost during 2-3 generations in laboratory media (Rittenberg et al., 1977) or 8-12 generations in guinea pig chamber fluid or serum (Goldner et al., 1979; Veale et al., 1981). Veale et al. (1981) showed that heat-inactivated human serum could induce serum resistance of gonococci similar to that obtained with guinea pig serum. However, in tests with suspensions containing about $10^{5}$ gonococci $\mathrm{ml}^{-1}$, only one of 13 human sera was as active as guinea pig sera in causing conversion to resistance. Here, human sera have been surveyed in conversion tests modified to include smaller numbers of gonococci.

\section{METHODS}

Neisseria gonorrhoeae |strain BS4 (agar)], media, culturing and counting procedures. These were as described previously (Veale et al., 1975; Penn et al.. 1976, 1977; Goldner et al., 1979).

Human serum. Blood samples collected by venous puncture from 36 donors (Batch 1) at the National Blood Transfusion Centre, Birmingham, were clotted for 5-6 h at room temperature. After standing for $24 \mathrm{~h}$ at $4{ }^{\circ} \mathrm{C}$ the sera were separated. filtered through Millipore filters $(0.22 \mu \mathrm{m})$ and stored at $-20^{\circ} \mathrm{C}$. After thawing quickly at $37^{\circ} \mathrm{C}$ the sera were heated $\left(56^{\circ} \mathrm{C}, 60 \mathrm{~min}\right)$ before use. Samples collected from 11 donors from the Department of Microbiology, University of Birmingham (Batch 2) were treated in the same way.

Guinea pig serum and defined medium. These were described by Veale et al. (1981).

Ultrafiltration. Sera were filtered at $4^{\circ} \mathrm{C}$ on XM-50 Diaflo membranes (which retain molecules of mol. wt $>50000$ ) in a $43 \mathrm{~mm}$ diameter pressurized cell (Amicon Corp.. Lexington, Mass., U.S.A.). The retained material (retentate) was washed twice with water (twice the original volume of serum) and made up to the original volume with water before testing. The XM-50 filtrates were either tested directly or, for some tests, were first concentrated 8- to 12-fold by filtration on a UM-2 membrane (which retains molecules of mol. wt $>1000$ ). In other tests the filtrates were passed through a YM-5 membrane (which retains molecules of mol. $w t>5000$ ), before concentration on a UM-2 membrane for testing. The YM-5 retentates were tested directly, i.e. in a volume $1 / 10-1 / 12$ of the original serum. The Diaflo membranes (XM-50, YM-5 and UM-2) were obtained from Amicon.

Generation of resistant organisms. The medium was a $1: 1$ mixture of defined medium and serum or serum fraction. In experiments with fractions obtained by ultrafiltration, the medium consisted of $50 \%(\mathrm{v} / \mathrm{v})$ serum fraction, $45 \%(v / v)$ defined medium and $5 \%(v / v)$ of a $2 \%(w / v)$ solution of bovine serum albumin (BSA; Sigma). The $\mathrm{pH}$ of the final mixtures was $6 \cdot 4-6 \cdot 8$. A suspension of gonococci in defined medium $(10 \mu \mathrm{l})$ was added to the medium $(100 \mu \mathrm{l})$; the inoculum size and the time and temperature of incubation are described in the text. Duplicate samples $(10 \mu \mathrm{l})$ of the mixture were plated before and after incubation to provide estimates of growth.

Measurement of resistance to killing by fresh (unheated) human serum. The test and method of expressing the degree of resistance were as described by Veale et al. (1981).

\section{RESULTS}

\section{The resistance-conferring capacity of human serum}

Attempts to convert inocula of $10^{6}-10^{7}$ gonococci $\mathrm{ml}^{-1}$ to serum resistance by incubation for $3 \mathrm{~h}$ at $37^{\circ} \mathrm{C}$ in human sera failed. However, when the inoculum size was reduced to about $5 \times 10^{4} \mathrm{ml}^{-1}\left(5 \times 10^{3} \mathrm{ml}^{-1}\right.$ in the incubation mixture), significant resistance-conferring capacity was demonstrated amongst the 47 sera examined (Table 1). In three experiments in which the conversion to resistance was $77 \%$ (s.E. $\pm 27 \%$ ) after $3 \mathrm{~h}$ at $37^{\circ} \mathrm{C}$, the conversion after $24 \mathrm{~h}$ was less than $5 \%$. During the $3 \mathrm{~h}$ incubation the bacterial concentration increased by 1.5-3.8 times; after $24 \mathrm{~h}$ it had increased by $700-1500$ times.

In three experiments with different batches of sera and an inoculum of $2-4 \times 10^{4}$ gonococci $\mathrm{ml}^{-1}, 40-90 \%$ conversion to resistance occurred at $37^{\circ} \mathrm{C}$ in $90 \mathrm{~min}$, and conversion was almost $100 \%$ after $3 \mathrm{~h}$. At $8^{\circ} \mathrm{C}$, however, conversion was insignificant $(<10 \%)$ even after $3 \mathrm{~h}$. After $3 \mathrm{~h}$ at $37^{\circ} \mathrm{C}$ the numbers of viable gonococci were $290 \%, 117 \%$ and $82 \%$ of those present initially, but at $8{ }^{\circ} \mathrm{C}$ only $70 \%, 12 \%$ and $36 \%$, respectively, of the initial viable gonococci survived after $3 \mathrm{~h}$, although much of the original inocula survived at $8^{\circ} \mathrm{C}$ for $90 \mathrm{~min}$. 
Table 1. Conversion of $N$. gonorrhoeae strain BS4 (agar) to serum resistance by incubation with some human sera

\begin{tabular}{lccccc} 
Sera in & \multicolumn{2}{c}{$\begin{array}{c}\text { No. of sera with which percentage } \\
\text { conversion to serum resistance } \dagger \text { was: }\end{array}$} & Estimated percentage growth \\
conversion medium & $\overbrace{\text { during conversion period } \ddagger}$
\end{tabular}

* Gonococci (about $5 \times 10^{4}$ colony-forming units $\mathrm{ml}^{-1}$ ) were diluted $1: 10$ in a medium comprising $50 \%$ $(\mathrm{v} / \mathrm{v})$ defined medium and $50 \%(\mathrm{v} / \mathrm{v})$ of the appropriate heat-inactivated $\left(56^{\circ} \mathrm{C}, 1 \mathrm{~h}\right)$ human serum $(\mathrm{pH}$ of final mixture $6.4-6.8$ ) and incubated for $3 \mathrm{~h}$ at $37^{\circ} \mathrm{C}$. See Methods for origin of serum batches 1 and 2 . Sera that converted more than $10 \%$ of the gonococci to serum resistance were tested at least twice; the remaining, inactive, sera were tested only once.

$\dagger$ Serum resistance was calculated as the number of colony-forming units recovered after incubation at $37{ }^{\circ} \mathrm{C}$ for $40 \mathrm{~min}$ with fresh human serum as a percentage of the count after a similar incubation in heated human serum (Veale et al., 1981).

$\ddagger$ Viable counts were not made at the beginning and end of the conversion period $(3 \mathrm{~h})$. Growth was estimated from the size of the inoculum and the viable counts in control tubes (containing heated human serum) at the end of the serum killing test (i.e. 40 min after the end of the conversion period).

The conversion experiments with human sera were conducted at $\mathrm{pH} \mathrm{6.4-6.8} \mathrm{because} \mathrm{of}$ previous results with guinea pig serum (Veale et al., 1981). In seven experiments, raising the $\mathrm{pH}$ of the conversion mixture to 6.9-7.3 resulted in reduced converting activity of three batches of human serum: conversion to serum resistance was reduced from more than $90 \%$ to less than $10 \%$.

A tendency for the converting capacity of active sera from donors HS and AAK (Batch 2) to increase with freezing and thawing prompted experiments in which converting capacity was examined before the sera had been frozen and after they had been frozen and thawed several times. Increasing inocula (from $1 \times 10^{3}$ to $1 \times 10^{6} \mathrm{ml}^{-1}$ ) of susceptible BS4 (agar) organisms were treated with each of the various samples of sera for $3 \mathrm{~h}$ at $37^{\circ} \mathrm{C}$ and the numbers of gonococci converted to resistance were calculated (Veale et al., 1981). In two experiments with different batches of AAK sera the mean numbers of BS4 (agar) that were resistant to killing by fresh human serum after $3 \mathrm{~h}$ at $37^{\circ} \mathrm{C}$ were $3.1 \times 10^{3}$ (s.E. $\left.\pm 1.7 \times 10^{3}\right) ; 7.8 \pm$ $4.5 \times 10^{4} ; 1.9 \pm 0.7 \times 10^{5} ; 5.0 \pm 1.8 \times 10^{5}$ and $6.3 \pm 5.3 \times 10^{5}$ when the sera had received $0,1,2,3$ and 4 cycles of freezing and thawing, respectively. In five experiments with different batches of HS sera the corresponding mean values were $2.9 \pm 2.5 \times 10^{3} ; 3.7 \pm 3.6 \times 10^{4}$; $8.5 \pm 1.6 \times 10^{4} ; 2.0 \pm 0.9 \times 10^{5}$ and $4.7 \pm 1.3 \times 10^{5}$. In all cases the number of gonococci increased 2 - to 3 -fold during the $3 \mathrm{~h}$ conversion period. There were no significant increases in the numbers of gonococci converted to resistance when either of the sera were frozen and thawed more than four times.

\section{Resistance-conferring capacities of high and low molecular weight fractions of human sera}

Several batches of human sera (AAK and HS) were filtered through Diaflo XM-50 membranes. The high molecular weight $(>50000)$ fraction retained the capacity to confer serum resistance, whereas the filtrate was not active when tested at a concentration equivalent to that of the original serum (Table 2). However, when the filtrate was concentrated on a UM-2 membrane, which retains molecules of molecular weight greater than 1000 , the concentrate converted gonococci to serum resistance. Furthermore, when the XM-50 filtrate was filtered on a YM-5 membrane, which retains molecules of molecular weight greater than 5000, the YM-5 retentate was inactive; but the YM-5 filtrate, when concentrated on a UM-2 membrane, had significant resistance-conferring capacity.

Like the low molecular weight resistance-conferring material in guinea pig serum (Veale et al., 1980) the corresponding material from human serum was found to be acid- and 
Table 2. Abilities of high and low molecular weight fractions of human sera to confer serum resistance on Neisseria gonorrhoeae strain BS4 (agar)

\begin{tabular}{|c|c|c|c|c|c|c|c|}
\hline \multicolumn{2}{|c|}{$\begin{array}{c}\text { Conversion medium } \\
\text { Defined medium containing: }\end{array}$} & \multicolumn{4}{|c|}{$\begin{array}{c}\text { No. of expts in which percentage } \\
\text { conversion to serum resistancet } \\
\text { was: }\end{array}$} & \multirow{2}{*}{$\begin{array}{l}\text { Mean } \\
\text { percentage } \\
\text { conversion } \\
\text { to serum } \\
\text { resistance }\end{array}$} & \multirow{2}{*}{$\begin{array}{c}\text { Mean percentage } \\
\text { growth during } \\
\text { conversion } \\
\text { period } \ddagger \\
( \pm \text { S.E. })\end{array}$} \\
\hline $\begin{array}{l}\text { Serum fraction } \\
\text { obtained by } \\
\text { ultrafiltration }\end{array}$ & $\begin{array}{c}\text { BSA } \\
(0.1 \% . w / v)\end{array}$ & $<10$ & $10-50$ & $51-90$ & $>90$ & & \\
\hline $\begin{array}{l}\text { XM-50 retentate } \\
(\mathrm{mol} . \mathrm{wt}>50000)\end{array}$ & - & 0 & 1 & 1 & 3 & 75 & $167 \pm 136$ \\
\hline $\begin{array}{l}\text { XM-50 filtrate } \\
(\mathrm{mol} \text {. wt }<50000)\end{array}$ & + & 5 & 0 & 0 & 0 & $<10$ & $254 \pm 106$ \\
\hline $\begin{array}{l}\text { XM-50 filtrate } \\
\text { concentrated } 8-12 \\
\text { times on UM-2 }\end{array}$ & + & 0 & 4 & 1 & 3 & 58 & $114 \pm 97$ \\
\hline $\begin{array}{l}\text { YM-5 retentate } \S \\
\text { (mol. wt }>5000) \\
\text { concentrated 8-12 } \\
\text { times }\end{array}$ & + & 4 & 0 & 0 & 0 & $<10$ & $106 \pm 78$ \\
\hline $\begin{array}{l}\text { YM-5 filtrate } \S \\
(\text { mol. wt }<5000) \\
\text { concentrated } 8-12 \\
\text { times on UM-2 }\end{array}$ & + & 0 & 3 & 0 & 3 & 64 & $89 \pm 28$ \\
\hline \multicolumn{8}{|c|}{$\begin{array}{l}\left.\text { * Gonococci (about } 5 \times 10^{4} \text { colony-forming units } \mathrm{ml}^{-1}\right) \text { were diluted in a medium comprising } 50 \%(\mathrm{v} / \mathrm{v}) \\
\text { defined medium (when BSA present, } 45 \% \text { defined medium and } 5 \%(\mathrm{v} / \mathrm{v}) \text { of a } 2 \%(\mathrm{w} / \mathrm{v}) \mathrm{BSA} \text { solution], and } \\
50 \%(\mathrm{v} / \mathrm{v}) \text { of a serum fraction prepared by ultrafiltration through Diaflo membranes (XM-50, YM-5 and UM-2) } \\
\text { as described in Methods. The serum fractions were prepared from at least three different batches of sera (HS and } \\
\text { AAK). The mixture (final pH } 6 \cdot 4-6.8) \text { was then incubated for } 3 \mathrm{~h} \text { at } 37^{\circ} \mathrm{C} \text {. } \\
+ \text { Calculated as for Table } 1 \text {. } \\
\$ \text { Obtained from viable counts at the beginning and end of the conversion period. } \\
\S \text { Prepared from the XM-50 filtrates, not directly from serum. }\end{array}$} \\
\hline
\end{tabular}

heat-labile. In three experiments with different sera (AAK and HS) the resistance of strain BS4 (agar) was reduced from $74 \%$ (s.E. $\pm 25 \%$ ) to less than $5 \%$ after treatment of the UM-2 concentrate (Table 2) at $75^{\circ} \mathrm{C}$ for $1 \mathrm{~h}$ at $\mathrm{pH} 7$ or at $37^{\circ} \mathrm{C}$ for $1 \mathrm{~h}$ at $\mathrm{pH} 2$.

\section{DISCUSSION}

A substantial number of human sera converted gonococci to serum resistance but these sera were less potent than guinea pig sera. Most samples of the latter could convert $10^{7}-10^{8}$ gonococci $\mathrm{ml}^{-1}$ (Veale et al., 1980), compared with about $10^{4}-10^{5}$ for human sera that had been frozen and thawed once. Thus, if similar factor(s) are responsible for conversion in both types of sera, then they are probably present in lower concentration in human sera, although factors other than concentration could affect converting activity. The resistance-converting factors were similar in the following respects: (i) in both guinea pig and human sera, resistance of gonococci appeared after $3 \mathrm{~h}$ at $37^{\circ} \mathrm{C}$ and was lost if incubation was continued for $24 \mathrm{~h}$; (ii) both sera were unable to convert gonococci to resistance at $8^{\circ} \mathrm{C}$ (Veale et al., 1981), suggesting that the gain of resistance was not due to adsorption of serum constituents but to their influence on an active metabolic event occurring at $37^{\circ} \mathrm{C}$; (iii) the resistance-conferring activity of both sera was greater at a slightly acid $\mathrm{pH}(6 \cdot 6)$ than at neutral $\mathrm{pH}$; and (iv) the increase in activity found following freezing and thawing of human serum was also observed with guinea pig serum (unpublished observations).

In addition to the parallels observed between human and guinea pig sera in experiments with whole sera, fractions obtained by membrane filtration also behaved similarly. The activity of the material from human sera that was retained by the XM-50 membrane 
resembled the activity of the non-dialysable material from guinea pig serum (Veale et al., 1981). The activity of the low molecular weight fraction from human serum was less than that of the high molecular weight fraction (Table 2). However, its similarity to the low molecular weight fraction from guinea pig serum prompted further investigation. The low molecular weight material from both human and guinea pig serum appeared to have a molecular weight between 1000 and 5000, and its activity was destroyed by heating to $75^{\circ} \mathrm{C}$ for $1 \mathrm{~h}$ or by incubating at $37^{\circ} \mathrm{C}$ for $1 \mathrm{~h}$ at $\mathrm{pH}$ 2. The parallel between the resistance-conferring factors of low molecular weight in human and guinea pig serum warrants fractionation of the material from the latter, which apparently contains the factor in greater concentration. If this factor can be identified, then human serum can be examined chemically for the same factors. Furthermore, if a more prolific source of the inducing factor were obtained, the way would be open to producing large quantities of resistant gonococci in vitro in order to investigate the determinants of serum resistance, which may play such an important role in the pathogenicity of gonococci in vivo.

\section{REFERENCES}

Brooks, G. F., Ingwer, I. \& Petersen, B. H. (1978). Importance of serum bactericidal and opsonic activity and complement in Neisseria gonorrhoeae infections. In Immunobiology of Neisseria gonorrhoeae, pp. 199-203. Edited by G. F. Brooks, E. C. Gotschlich, K. K. Holmes, W. D. Sawyer \& F. E. Young. Washington, D.C.: American Society for Microbiology.

Goldner, M., Penn, C. W., Sanyal, S. C., Veale, D. R. \& SMITH, H. (1979). Phenotypically determined resistance of Neisseria gonorrhoeae to normal human serum: environmental factors in subcutaneous chambers in guinea pigs. Journal of General Microbiology 114, 169-177.

McCutchan, J. A., Levine, S. \& Braude, A. I. (1976). Influence of colony type on susceptibility of gonococci to killing by human serum. Journal of Immunology 116, 1652-1655.

Penn, C. W., Sen, D., Veale, D. R., Parsons, N. J., SMith, H. \& WITT, K. (1976). Morphological, biological and antigenic properties of Neisseria gonorrhoeae adapted to growth in guinea pig subcutaneous chambers. Journal of General Microbiology 97, 35-43.

Penn, C. W., Veale, D. R. \& Smith, H. (1977). Selection from gonococci grown in vitro of a colony type with some virulence properties of organisms adapted in vivo. Journal of General Microbiology 100, 147-158.

Rittenberg, S. C., PenN, C. W., Parsons, N. J.,
Veale, D. R. \& Smith, H. (1977). Phenotypic changes in the resistance of Neisseria gonorrhoeae to killing by normal human serum. Journal of General Microbiology 103, 69-75.

Schoolnik, G. K., Buchanan, T. M. \& Holmes, K. K. (1976). Gonococci causing disseminated gonococcal infection are more resistant to the bactericidal action of normal human sera. Journal of Clinical Investigation 58, 1163-1173.

Veale, D. R., Smith, H., Witt, K. A. \& Marshall, R. B. (1975). Differential ability of colonial types of Neisseria gonorrhoeae to produce infection and an inflammatory response in subcutaneous perforated plastic chambers in guinea pigs and rabbits. Journal of Medical Microbiology 8, 325-335.

Veale, D. R., PenN, C. W., Parsons, N. J. \& Smith, H. (1980). Preliminary studies of a factor in guinea pig serum which induces serum resistance in Neisseria gonorrhoeae. Society for General Microbiology Quarterly 7, 188.

Veale, D. R., PenN, C. W. \& Smith, H. (1981). Factors affecting the induction of phenotypically determined serum resistance of Neisseria gonorrhoeae grown in media containing serum or its diffusible components. Journal of General Microbiology 122, 235-245.

WARD, M. E., WATt, P. J. \& GLYNN, A. A. (1970). Gonococci in urethral exudates possess a virulence factor lost on subculture. Nature, London 227, 382-384. 